EISSN: 2706-7955 ISSN: 2077-4605

DOI: 10.36632/mejar/2021.10.3.55

Journal homepage: www.curresweb.com

Pages: 820-826

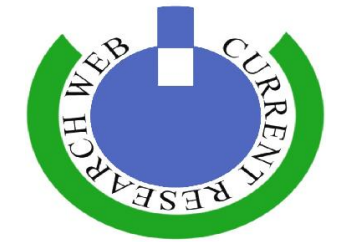

\title{
Evaluation of Lead Deposit and Fertility Indices of Lowland Rice Fields in Rock Mining Areas of Ishiagu, Southeastern Nigeria
}

Nwite J.C ${ }^{1}$ and B.O. Unagwu ${ }^{2}$

\author{
${ }^{I}$ Department of Crop Production Technology, Federal College of Agriculture, Ishiagu, Ebonyi \\ State, Nigeria. \\ ${ }^{2}$ Department of Soil Science, University of Nigeria, Nsukka, Enugu State, Nigeria.
}

Received: 22 June 2021 Accepted: 10 July $2021 \quad$ Published: 15 July 2021

\begin{abstract}
The present study assessed the effect of quarrying on topsoil lead deposit and selected soil fertility indices of lowland rice fields in Ishaigu, Ebonyi State. A purposeful sampling technique was used in selecting the locations evaluated in this study. The locations were: Danger zone, which is where industrial waste waters/ effluents are discharged to, Ngwogwo and Okue locations are the mining areas, while Ovumte served as the control location. Two sets of factors used in this study were: four locations (Factor A) which constitute the main plot and three toposequence positions (upper, middle and bottom) (Factor B) which served as the sub-plots. Nine soil auger samples were collected randomly from each of the locations at 0 to $40 \mathrm{~cm}$ depth. Soil parameters were evaluated; soil $\mathrm{pH}$, organic carbon, total nitrogen, cation exchange capacity, and lead concentration. Results showed that lowlands of danger zone had the highest $(0.075 \mathrm{mg} / \mathrm{kg}, \mathrm{p}<0.05)$ lead deposit while Ovumte recorded the least $(0.015$ $\mathrm{mg} / \mathrm{kg}, \mathrm{p}<0.05$ ) lead deposit. Results also revealed that other soil parameters studied were significantly $(\mathrm{p}<0.05)$ higher in Ovumte lowland area than those other lowlands around the Crush Rock Industry. Based on Bowen (1979) and EU lead recommended level (35 mg/kg), lead contamination is no threat to lives and agricultural production across the study locations. However, the soil quality for crop production is compromised. This suggests that mining operations by Crush Rock industry impact negatively on the fertility indices of the study area.
\end{abstract}

Keywords: Lead deposit, toposequences, lowlands, crush rock industry, fertility indices, heavy metals

\section{Introduction}

Quarrying is an operation that involve the removal of over burden, drilling, blasting and crushing of rock materials. The impact of quarrying operations and their by-products depend on the size (magnitude) and location of the quarry (Enger and Smith, 2002). A wide variety of products obtained by mining and crushing of rocks form the principal raw materials used for most industrial applications (Ellen, 2000). For instance, Wills (1995) noted that crushed rocks could be used in highways or concrete construction, in bituminous mixture and railroad ballast. Unfortunately, several wastes are generated during rock extraction impact negatively on the air, water, and soil quality as well as the earth surface, flora and fauna, and human beings (Enger and Smith, 2002). The adverse effects of rock extractions on soil physical and chemical properties can possibly affect the soil forming processes and plant growth performance depending on the mineral components of the rock extracted. In overburden dumps, besides increases in the metal concentration, Maiti (2007) reported significant decreases in soil properties such as exchangeable cations, available nutrients, organic carbon content, etc.

Soil is the cross road and link between water, air and mineral cores. The physical and chemical soil properties as well as soil organisms. To a greater extent, determine the crop type to be grown (Sahai et al., 1985). Wastes (effluents) from quarries affect not only the environment but also disturb the soil rhizosphere (Sen, 1998). Ghosh and Saxena (1995) submitted that soil properties in effluent-polluted soils recorded lower cation exchange capacity (CEC), total porosity and water holding capacity relative 
to the unpolluted soil. Sadhu et al. (2012) reported that mined soils are associated with lower soil nutrients such as available nitrogen, available phosphorus and available potassium as compared with the native (unmined) soils. From literature, the organic carbon content of native soils is higher than those of mined soils. Sadhu et al. (2012) also asserted that mining activity affected the soil CEC relative to the native soil. This suggests that mining and mining associated activities have damaging effects on soil quality.

Nwaugo et al. (2007), in their study on post operational effects of quarry mining on soil quality in Ishiagu, found high level of $\mathrm{Pb}, \mathrm{Zn}$, nitrate, $\mathrm{Cd}$ and other metals in the soil following quarrying activities in the study area. Quarrying and its activities contaminate the soil leading to presence of heavy metals. Rani et al. (2017) reported that quarrying/crushing activities contribute to soil fertility degradation. The spent explosives, crushed rock debris dumps as well as the waste water generated from rock crushing affect soil organic carbon and nitrogen contents of nearby agricultural fields (Rani et al., 2017). During raining season, runoff from the dumps and waste materials from crushed rock operations can contribute to soil degradation thus affecting the soil fertility status of the surrounding agricultural fields. Rani et al. (2017) reported that N, P and K values increased with increase in distance away from the quarrying and crushing operation sites. According to Kalu (2018), stone quarrying activities caused different environmental issues in Ebonyi State which negatively affected the air, water and soil quality around the host communities. The disregard of pollution limits by most quarrying industries and low adherence to environmental and safety laws by quarry operators contribute to increased heavy metals deposit and a general decline in soil fertility status (Adekoya, 1995).

For over 20 years, there has been mining activities by Crush Rock Industry Ltd in Ishiagu. Following reviews on the effects of quarrying activities on the environment, thus, there is a perceived danger of metal contamination, especially lead, since lead mining is common in Ishiagu. Till date, sparse study has been carried out to ascertain the impact of the Crush Rock quarrying activities on the soil properties of Ishiagu community. This study evaluated the effect of Crush Rock Industry Ltd quarrying activities on soil properties and lead contamination especially, for the communities that are close to the mine site.

\section{Materials and Methods}

\subsection{Description of the Study Area}

Ishiagu is located between latitude $5^{\circ} 55^{\prime} \mathrm{N}$ and $6^{\circ} 00^{\prime} \mathrm{N}$ and longitudes $7^{\circ} 30^{\prime} \mathrm{E}$ and $7^{\circ} 35^{\prime} \mathrm{E}$. The relief of the study area is low-lying and undulating (Eze and Chukwu, 2011). The mean annual rainfall and mean monthly temperature were $1350 \mathrm{~mm}$ and $30^{\circ} \mathrm{C}$, respectively. The area lies within the derived savanna vegetative zone of South Eastern Nigeria. There are two distinct seasons, the dry season which spans November to March, at times extend to April, and the rainy season which spans April to October (Nwite et al., 2008).

\subsection{Geology and Soils of the Study Area}

The geology of the area is of sandy shales, with fine grained micaceous sandstones and mudstones that is Albian in age and belongs to the Asu River Group. Generally, it has dark coloured shales and mudstones. The dark coloured shales are formed in stagnant marine basins and they contain sulphide minerals and large quantities of organic matter (Eze and Chukwu, 2011). The soil is classified as Ultisol, which is hydromorphic and of shale parent material with underlying impervious layer at about $40 \mathrm{~cm}$ depth. It is characterized by rampant flooding and water logging as result of poor drainage due to the impervious layer, high soil bulk density and crusting (FDALR 1985).

\subsection{Field study}

The study was conducted in 2019 at four different locations in Ishiagu, Ivo Local Government Area of Ebonyi State, Southeastern Nigeria. The locations include: one lowland rice field each from the two communities (Okue and Ngwogwo) out of the three communities that host the Crushed Rock Industry (a German owned Industry). The third location was a lowland field called "Danger zone", which contains pits where waste water from the Industry are discharged into. The waste water from the danger zone usually gets distributed to the lowlands rice fields of the three communities hosting the 
Industry. The fourth location was a lowland rice field at Ovumte community, which is three kilometers away from the Industry. The choice of collecting soil samples from the Okue and Ngwogwo lowlands rice fields as well as the danger zone was to ascertain the extent of soil fertility and lead deposit variations due to the activities of Crush Rock Industry Ltd. Ovumte lowland rice field, which do not receive any discharge from the industry served as the control.

\subsection{Collection of Soil Samples}

Purposeful and random sampling methods were used to collect soil samples from the four locations. Purposeful sampling is a sampling technic where questionnaires or interviews are used to select target audience or respondents or areas. Purposeful sampling helps researchers select their target area based on choice. Thus, the selection of the aforementioned four locations was based on choice as there are other areas in Ishiagu where mining activities are carried out. Two sets of factors used to assess soil parameters variation in this study were: the four locations constituted the main plot, while three different toposequence positions (upper, middle and bottom) as the sub-plots. During soil sampling and collection, nine soil auger samples were randomly collected from each location at a depth of 0 to 40 $\mathrm{cm}$, giving a total of 36 soil samples. A 0 to $40 \mathrm{~cm}$ soil depth is regarded an agricultural plough layer because it is the seat of essential plant growth nutrients and the maximum rooting depth for most arable crops (Ezeaku et al., 2002).

The auger soil sampling was taken from three sampling points across each slope position representing the blocks/replicates in the study design. The auger soil samples were stored in labeled polythene bags. The soil samples were air-dried under shade for three days, crushed, sieved with a 2 $\mathrm{mm}$ sieve and taken to the laboratory for the determination of the following soil parameters. Soil $\mathrm{pH}$ was measured in a 1:2.5 (soil:0.1 M KCl) suspensions (McLean, 1982). The Walkley and Black method as described by Nelson and Sommers (1996) was used in determining soil organic carbon. The total nitrogen was determined by Bremmer and Mulvancy (1982) method. The CEC was determined by the method (Rhoades, 1982). Anderson (1974) double acid digestion technique was used in sample extraction using $\mathrm{HCl} . \mathrm{HNO}_{3}$ to digest the soils for the heavy metal analysis. Lead concentration was determined with the aid of Instrumentation Laboratory IL251 Atomic Absorption Spectrophotometer.

\subsection{Data Analysis}

Data analysis was evaluated by an analysis of variance (ANOVA) of split-plot in a randomized complete block design using GENSTAT 3, 7.2 Edition. The least Significant Difference (LSD) was to separated and compared treatment means at $5 \%$ probability level.

\section{Results and Discussion}

\subsection{Effects of quarrying activities onlead deposit and soil $\mathbf{p H}$}

The data obtained (Table 1) indicated that the highest $(0.074 \mathrm{mg} / \mathrm{kg}, \mathrm{p}<0.05)$ lead concentration was found in the danger zone, where the industrial wastes (waste water and spoil dumps) are discharged. It was observed that lowland rice fields where wastes discharge from the Crush Rock Industry do recharge by either surface or underground water significantly $(p<0.05)$ increased the topsoil lead deposit more than the lowland rice filed of Ovumte that is three kilometers away from the industry and receives no discharge from the industrial wastes. However, the results (Table 1) indicated that despite the high level of lead deposit in the three locations that receives effluents/wastes from the industry, the topsoil lead concentration is still below the permissible level $35 \mathrm{mg} / \mathrm{kg}$ according to Bowen (1979) in Aydinalp and Marinova (2003) and the EU recommended level.

Across locations, slope positions vary significantly $(p<0.05)$ on the topsoil lead deposit. The bottom slope in the four locations recorded the highest topsoil lead deposit. This could be attributed to upstream erosion which, according to Oo et al. (2012), results not only in siltation and sedimentation of downstream water bodies and paddy fields but also in transporting nutrients contained in the sediments and irrigation waters. In the event of erosion sediment rich in nutrients and other materials are moved and reallocated to watershed such that the distribution of the sediments is unequal at the lowlands (Dung et al., 2008). The sediments deposited cause spatial variation in soil fertility and heavy metal concentrations in downstream watersheds (Gao et al., 2007; Mingzhou et al., 2007). 
Soil $\mathrm{pH}$ significantly $(\mathrm{p}<0.05)$ vary among the locations with the highest significant $\mathrm{pH}$ recorded in the Ovumte lowland rice field. It was obtained that the danger zone lowland where the industrial wastes are directly discharged lowered its $\mathrm{pH}$ to acidic level (4.78) as against $7.29 \mathrm{pH}$ obtained from Ovumte. Ghose (2004) reported that mining lowers fertility indices of affected area when compared to a native soil. Results (Table 1$)$ also indicated that upper slope position significantly $(\mathrm{p}<0.05)$ increased the $\mathrm{pH}$ (6.42) higher than other slope positions studied. Soil $\mathrm{pH}$ is one critical factor that influence heavy metal solubility (Zhong et al., 2020). Study has shown that heavy metal ( $\mathrm{Zn}, \mathrm{Cu}, \mathrm{Fe}, \mathrm{Pb}$ ) solubility and bioavailability increase as soil $\mathrm{pH}$ decrease (Hou et al., 2019). . In addition to the effect of waste discharge to the Danger Zone, the significantly $(\mathrm{p}<0.05)$ low $\mathrm{pH}$ associated with Danger Zone relative to Ngwogwo, Okue and Ovumte contributed to the observed high lead concentrated. Since $\mathrm{pH}$ moderates lead activity (solubility and bioavailability), there is tendency of lead accumulation by plant over time.

Table 1: Influence of Crush Rock Industry on the lead ( $\mathrm{mg} / \mathrm{kg}$ ) deposits and soil $\mathrm{pH}$ variations in the lowland rice fields in the host communities

\begin{tabular}{|c|c|c|c|c|c|}
\hline \multirow{2}{*}{ Slope Positions } & \multicolumn{4}{|c|}{ Locations } & \multirow[t]{2}{*}{ Mean } \\
\hline & Danger zone & Ngwogwo & Okue & Ovumte & \\
\hline \multicolumn{6}{|c|}{ Lead $(\mathrm{mg} / \mathrm{kg})$} \\
\hline Upper slope & 0.044 & 0.028 & 0.027 & 0.017 & 0.029 \\
\hline Middle slope & 0.088 & 0.032 & 0.038 & 0.019 & 0.041 \\
\hline Bottom slope & 0.092 & 0.029 & 0.040 & 0.020 & 0.046 \\
\hline Mean & 0.075 & 0.029 & 0.035 & 0.015 & 0.039 \\
\hline \multicolumn{3}{|c|}{ LSD (0.05) Slope positions } & 0.004 & & \\
\hline \multicolumn{3}{|c|}{ LSD (0.05) Locations } & 0.006 & & \\
\hline \multicolumn{3}{|c|}{ LSD $(0.05)$ Slope positions $x$ locations } & 0.009 & & \\
\hline \multicolumn{6}{|c|}{ (2) } \\
\hline Upper slope & 4.97 & 6.40 & 7.53 & 6.80 & 6.43 \\
\hline Middle slope & 4.87 & 6.60 & 5.93 & 7.33 & 6.18 \\
\hline Bottom slope & 4.50 & 6.27 & 6.10 & 7.73 & 6.15 \\
\hline Mean & 4.78 & 6.42 & 6.52 & 7.29 & 6.25 \\
\hline \multicolumn{3}{|c|}{ LSD (0.05) Slope positions } & 0.223 & & \\
\hline \multicolumn{3}{|c|}{ LSD (0.05) Locations } & 0.218 & & \\
\hline \multicolumn{3}{|c|}{ LSD (0.05) Slope positions $x$ locations } & 0.364 & & \\
\hline
\end{tabular}

\subsection{Effects of quarrying on soil organic carbon $\left(\mathrm{g} \mathrm{kg}^{-1}\right)$, total nitrogen $\left(\mathrm{g} \mathrm{kg}^{-1}\right)$ and cation exchange} capacity (CEC) $\left(\mathrm{cmol} \mathrm{kg}^{-1}\right)$

The mean Soil organic carbon (SOC) was significantly $(\mathrm{p}<0.05)$ higher $(14.21 \mathrm{~g} / \mathrm{kg})$ for soil in Ovumte location than soils of the other three locations (Table 2). The low SOC associated with soils around the Crush Rock Industry could be attributed to the effect of waste materials discharged from the Crush Rock Industry. The present result is in conformity with the findings of Sadhu et al. (2012) that the soil organic content of mine spoil soil was significantly lower by $39 \%$ to $56 \%$ less relative to the organic carbon content of the native soil. This suggests that the mining have damaging effects on the quality of soils around the mining area. Results (Table 2) show that upper slope position had significantly $(\mathrm{p}<0.05)$ higher soil organic carbon $(11.07 \mathrm{~g} / \mathrm{kg})$ among the studied slopes. The significantly low SOC observed down the slope can be attributed to impact of erosion long the slope gradient.

The results (Table 2) indicate that total nitrogen did not differ significantly $(\mathrm{p}<0.05)$ across the slope position even though the bottom slopes had lower total nitrogen relative to the upper and middle slopes. More so, the study locations did not differ statistically in their total nitrogen content, although Ovumte mean total nitrogen content was higher relative to those of Danger Zone, Ngwogwo and Okue. A similar study by Sadhu et al. (2012) showed that soil nutrients like available nitrogen, phosphorus and potassium are lower in mining areas with respect to native soils. As anticipated, the mean Cation exchange capacity (CEC) was significantly $(\mathrm{p}<0.05)$ higher $\left(20.4 \mathrm{cmol} \mathrm{kg}^{-1}\right)$ for Ovumte compared to Danger Zone, Ngwogwo and Okue (Table 2). The finding is in agreement with the submissions of Ghosh and Saxena (1995) that the soil CEC, are generally reduced in effluent-polluted soils. Sadhu et al. (2012) also reported that CEC is disturbed by mining activity as compared to their nearest native 
soils. It was obtained that CEC varied significantly $(p<0.05)$ across the slope positions with upper and downstream slopes showing higher and lower CEC levels, respectively. The variations across the slope positions could be attributed to unequal distribution of sediments which created observed spatial variability (Gao et al., 2007; Mingzhou et al., 2007).

Table 2: Influence of quarrying on the soil organic carbon $\left(\mathrm{g} \mathrm{kg}^{-1}\right)$, total nitrogen $\left(\mathrm{g} \mathrm{kg}^{-1}\right)$ and cation exchange capacity (CEC) $\left(\mathrm{cmol} \mathrm{kg}^{-1}\right)$ variations in the lowland rice fields in the host communities

\begin{tabular}{|c|c|c|c|c|c|}
\hline \multirow{2}{*}{ Slope Positions } & \multicolumn{4}{|c|}{ Locations } & \multirow{2}{*}{ Mean } \\
\hline & Danger zone & Ngwogwo & Okue & Ovumte & \\
\hline \multicolumn{6}{|c|}{ Soil organic carbon $(\mathrm{g} / \mathrm{kg})$} \\
\hline Upper slope & 11.18 & 9.87 & 5.91 & 17.33 & 11.1 \\
\hline Middle slope & 6.88 & 7.85 & 2.60 & 12.45 & 7.44 \\
\hline Bottom slope & 5.27 & 2.49 & 3.82 & 12.84 & 6.10 \\
\hline Mean & 7.77 & 6.74 & 4.11 & 14.21 & 8.21 \\
\hline \multicolumn{3}{|c|}{ LSD (0.05) Slope positions } & 1.221 & & \\
\hline \multicolumn{3}{|c|}{ LSD $(0.05)$ Locations } & 1.819 & & \\
\hline \multicolumn{3}{|c|}{ LSD (0.05) Slope positions $x$ locations } & NS & & \\
\hline \multicolumn{6}{|c|}{ Total nitrogen (g/kg) } \\
\hline Upper slope & 0.77 & 0.65 & 0.75 & 1.17 & 0.83 \\
\hline Middle slope & 0.75 & 0.90 & 0.82 & 0.93 & 0.85 \\
\hline Bottom slope & 1.40 & 0.74 & 0.72 & 1.30 & 1.04 \\
\hline Mean & 0.97 & 0.76 & 0.76 & 1.14 & 0.908 \\
\hline \multicolumn{3}{|c|}{ LSD (0.05) Slope positions } & NS & & \\
\hline \multicolumn{3}{|c|}{ LSD (0.05) Locations } & NS & & \\
\hline \multicolumn{3}{|c|}{ LSD (0.05) Slope positions x locations } & NS & & \\
\hline \multicolumn{6}{|c|}{ Cation exchange capacity $\left(\right.$ CEC) $\left(\mathrm{cmolkg}^{-1}\right)$} \\
\hline Upper slope & 18.4 & 15.4 & 13.3 & 21.2 & 17.1 \\
\hline Middle slope & 11.8 & 16.9717 .0 & 10.9 & 17.5 & 14.3 \\
\hline Bottom slope & 10.8 & 16.4 & 14.9 & 22.6 & 16.2 \\
\hline Mean & 13.7 & 16.3 & 13.0 & 20.4 & 15.8 \\
\hline \multicolumn{3}{|c|}{ LSD (0.05) Slope positions } & 1.859 & & \\
\hline \multicolumn{3}{|c|}{ LSD (0.05) Locations } & 1.403 & & \\
\hline \multicolumn{3}{|c|}{ LSD (0.05) Slope positions $x$ locations } & 2.515 & & \\
\hline
\end{tabular}

\section{Conclusion}

There were significant variations in lead deposit across locations and slopes. Results showed that lead content were lower than the Bowen (1979) and EU recommended level $(35 \mathrm{mg} / \mathrm{kg})$. Notwithstanding the low lead concentration, results showed that the soil quality for crop production is under threat with respect to soil $\mathrm{pH}$, organic carbon and CEC. This suggests that the activities of Crush Rock Industry has significant negative effects on the fertility indices of lowlands in the study area.

Nevertheless, the observed low lead concentration for soils in locations around the Crush Rock Industry, does not guarantee the future safety of the soil and environments of the host communities. This is because lead pollutant may gradually build up. And because lead forms complexes which are not being easily leached out or affected by other chemical composition, check and balance mechanism is critical to forestall future harm to host community. Farmers in the study area need a management strategy to overcome low soil fertility and future lead contamination that is associated with the activities of Crush Rock Industry. This can be achieved through adequate use of manures and other organic amendments to reduce metal solubility and concentration as well as improve the overall soil health.

\section{Conflict of interest}

We, the authors, declare that, there is no conflict of interest regarding this study. 


\section{References}

Adekoya, J.A., 1995. Negative environmental impact of mineral exploitation in Nigeria. J Phys Sch., 12:613-619

Anderson, J., 1974.Wet Digestion versus Dry for the Analysis of Fish Tissue for Trace Metals. Afon Absorption Newsletter 11:88-89.

Aydinalp, C., and S. Marinova, 2003. Distribution and Forms of Heavy Metals in Some Agricultural Soils. Polish J Environ Studies 12(5):629-633.

Dung, N.V., T.D. Vien, N.T. Lam, T.M. Tuong, and G. Cadish, 2008. Analysis of the sustainability within the composite swidden agroecosystem in northern Vietnam 1, Partial nutrient balance and recovery times of upland fields. Agric Ecosys Environ., 128(1-2):37-51.

Enger, E.D. and B.F. Smith, 2002. Environmental Science: A study of Interrelationship (8th edition) McGraw Hill Higher Education, New York, pp 370-380.

Eze, H.N. and E. Chukwu, 2011. Small scale mining and heavy metals pollution of agricultural soils: The case of Ishiagu Mining District, South Eastern Nigeria. J Geo Mining Res., 3(4):87-104.

Ezeaku, P.I., F.O.R. Akamigbo, and C.L.A. Asadu, 2002. Maize yield predictions based on soil fertility parameters in southeastern Nigeria. J Agro- Tech. Ext., 2(2):30-38.

Federal Department of Agriculture Land Resources (FDALR), 1985. Reconnaissance Soil Survey reports of Anambra, Cross Rivers, Imo and Rivers StatesAgriculture Land Resources. Tech Bulletin 5:12-20.

Gao, P, G.B. Pasternack, K.M. Bali, W.W. Wallender, 2007. Suspended-sediment transport in an intensively cultivated watershed in southeastern California. Catena 69(3):239-252.

Ghose, M.K., 2004. Effect of opencast mining on soil fertility. J environ and industrial Res 63:10061009

Ghosh, R. and N.C. Saxena, 1995. Small scale mining environmental impacts, 67, 1995, 95

Hou, S., N. Zheng, L. Tang, J. Xiaofeng and L. Yunyang, 2019. Effect of soil pH and organic matter content on heavy metals availability in maize (Zea mays L.) rhizospheric soil of non-ferrous metals smelting area. Environ Monit. Assess 191:634-644.

Kalu, E., 2018. Environmental Impact of Stone Quarrying Activities in Ebonyi State, Nigeria. J Advanced Studies in Agric, Biological and Environ Sci., 5(2):7-22.

Maiti, S.K., 2007. Bioreclamation of coalmine overburden dumps with special emphasis on micronutrients and heavy metals accumulation in tree species. Environ Monit Assess., 125(13):111-122.

McLean, E.O., 1982. Soil pH and lime requirement. In: Page AL, Miller RH, Keeny DR, (eds.). Methods of Soil Analysis, Part 2. Am. Soc. Agron. Madison, pp 199-224.

Mingzhou, Q., R.H. Jackson, Y. Zhongjin, M.W. Jackon and S. Bo, 2007. The effects of sediment-laden waters on irrigated lands along the lower Yellow River in China. J Environ. Manage., 85(4):858865.

Nelson D.W . and L.E. Sommers, 1996. Total carbon, total organic carbon and organic matter. In: Sparks DL, (ed.). Methods of soil analysis, part 3: Chemical methods. Agronomy Monograph No 9. American Society of Agronomy, Madison, pp 961-1010.

Nwaugo, V.O., S.O. Qbiekezie and C.A. Etok, 2007. Post operational effects of heavy metal mining on soil quality in Ishiagu, Ebonyi State, Nigeria. Int. J Biotechnol Allied Sci., 2:242-246.

Nwite J.C., C.A. Igwe, and T. Wakatsuki, 2008. Evaluation of sawah rice management system in an inland valley in southeastern Nigeria. I: Soil chemical properties and rice yield. Paddy Water Environ., 6: 299-307.

Oo Az, S.D. Kimura, K.T. Win, Nx Huu, L. Nguyen and G. Cadisch, 2012. Effect of Toposequence Position on Soil Properties and Crop Yield of Paddy Rice in Northern Mountainous Region, Vietnam. JIFS 9:59-65.

Rani H.B., S. Swamy, A.L. Bharath, R. Prasad, H. Dinakar and A.V. Raghu, 2017. Impact of Quarrying and Crushing on Soil Quality: A Case Study in Tumkur District, Karnataka." Int. J Res. Granthaalayah, 5(4):11-16.

Rhoades, J.D., 1982. Cation exchange capacity. In: Page AL (ed.), Methods of soil analysis, Part 2Chemical and microbiological properties $\left(2^{\text {nd }} e d n\right)$. Agronomy Monograph no 9. Madison, $p p$ 149-157. 
Sadhu, K., K. Adhikari, and A. Gangopadhyay, 2012. Effect of mine spoil on native soil of Lower Gondwana coal fields: Raniganj coal mines areas, India. Int J Environ. Sci., 2:(3) 1675-1687.

Sahai R, N. Shukla, S. Jabeen, and P.K. Saxena, 1985. Pollution effect of distillery waste on the growth behaviour of Phaseolus radiatus L. Environmental Pollution Series A. Ecological and Bio., 37(3):245-253.

Sen, A.K., 1998. Mortality as an Indicator of Economic Success and Failure. The Economic J., 108(446):1-25.

Wills M.C., 1995. Studies of Copper and Zinc forms in some Polish and Egyptian Soils, Part II, Distribution of some Copper and Zinc in Soil Profiles. Polish J Soil Sci., 2(1): 34-41.

Zhong, Xi, Z. Chen, Y. Li, K. Ding, W. Liu, Y. Liu, Y. Yuan, M. Zhang, A.J.M. Baker, W. Yanga, Y. Fei, Y. Wang, Y. Chao, and R. Qiu, 2020. Factors influencing heavy metal availability and risk assessment of soils at typical metal mines in Eastern China. J Hazardous Materials, 400:123-129. 